\title{
PENGEMBANGAN MULTIMEDIA PENDIDIKAN JASMANI MATERI BUDAYA HIDUP SEHAT UNTUK SEKOLAH MENENGAH ATAS
}

\author{
DEVELOPING PHYSICAL EDUCATION MULTIMEDIA \\ FOR HEALTHY LIFE CULTURE MATERIAL FOR SENIOR HIGH SCHOOLS
}

\author{
Arief Fitriadi, Hari Amirullah Rachman \\ - , Universitas Negeri Yogyakarta \\ arief.fik@gmail.com, harirachman@yahoo.com.au
}

\begin{abstract}
Abstrak
Penelitian ini bertujuan untuk menghasilkan sebuah produk berupa multimedia pembelajaran pendidikan jasmani materi budaya hidup sehat dalam bentuk buku dan CD (Compact Disk). Jenis penelitian adalah Research and Development ( $\mathrm{R}$ and $\mathrm{D})$ dengan pendekatan survei melalui tes pengukuran. Penelitian pengembangan ini melalui empat tahapan, yaitu pendahuluan, tahap pengembangan, tahap uji lapangan dan tahap desiminasi produk. Populasi penelitian adalah siswa kelas X dan kelas XI SMA Negeri se-Kabupaten Yogyakarta sebanyak 83 orang. Instrumen pengumpulan data adalah lembar validasi untuk ahli materi dan ahli media, serta lembar kuesioner untuk siswa SMA. Hasil penelitian menunjukkan sebagai berikut: (1) Hasil validasi oleh ahli materi menilai "Sangat Mudah". Dari ahli media menilai "Sangat Mudah". Rata-rata hasil uji lapangan kelas X menunjukkan bahwa aspek pengoperasian CD "Baik", aspek pembelajaran CD "Baik", aspek pembelajaran buku "Baik", dan aspek kemenarikan CD "Sangat Mudah". Untuk kelas XI aspek pengoperasian CD "Sangat Baik", aspek pembelajaran CD "Baik", aspek pembelajaran buku "Baik", dan aspek kemenarikan CD "Baik".
\end{abstract}

Kata Kunci: Multimedia, budaya hidup sehat.

\begin{abstract}
This study aims to produce learning softwere for physical education for healty life culture materials in form of a book and a Compact Disk $(C D)$. This was a research and development $(R \& D)$ study employing the survey approach through testing and meansurement. The study was sondusted in four stages, namely a preliminary study, development, field testing, and product dissemination. The research population comprised Grades X and XI students of senior high schools (SHSs) in Yogyakarta City. The research subjects were 83 people. The data collecting instrument included validation sheets for the material and media expert, and a questionnaire for SHS students. The data collecting techniques include questionnaire, observation and interview methods. The data were collected through a questionnaire for the expert and and the students' responses to the media. They were descriptively analized.The result of the study are as follows. (1) The results of the validation by material expert show that it is very easy. Meanwhile, according to the media expert, it is very easy. The results of the field tryout for Grade X show that the CD operation obtain "Good". For Grade XI the CD operation aspect obtains "Good", the CD learning obtains "Very Good", the book learning aspect obtains "Good" and the CD attractivenes aspect obtains "Good".
\end{abstract}

Keywords: Multimedia, healthy life culture 


\section{Pendahuluan}

Pendidikan pada hakikatnya adalah upaya sadar dari suatu masyarakat dan pemerintah suatu negara untuk menjamin kelangsungan hidup dan kehidupan generasi penerusnya selaku warga masyarakat, bangsa dan negara. Dalam pengertian tersebut seharusnya ada usaha dari dalam diri seseorang untuk menjamin kelangsungan hidup sendiri bukan paksaan dari orang lain atau faktor eksternal. Oleh karena itu siswa harus ada kemauan dari diri sendiri untuk bisa memajukan diri agar mampu bermanfaat bagi orang lain.

Tugas seorang siswa adalah belajar namun belakangan para generasi penerus bangsa tersebut tidak melaksanakan tugasnya sebagai siswa, bisa dilihat dari maraknya tawuran sesama pelajar baik sekolah pertama maupun tingkat atas. Belajar adalah proses yang terus menerus, tidak pernah berhenti dan tidak terbatas pada dinding kelas. Belajar dianggap sebagai proses perubahan perilaku sebagai akibat dari pengalaman dan latihan. Hilgard (Sanjaya, 2009, p.112) mengungkapkan belajar adalah proses perubahan melalui kegiatan atau prosedur latihan (baik latihan dalam laboratorium maupun dalam lingkungan ilmiah).

Menurut Geagne (Dahar, 1996, p.11) belajar didefinisikan sebagai suatu proses di mana suatu organisme berubah perilaku sebagai akibat dari pengalaman. Namun pada kenyataannya sekarang ini banyak siswa yang berurusan dengan hukum, mulai dari tawuran antarsiswa, penggunaan narkoba bahkan hingga tindakan prostitusi. Tawuran pelajar sekolah menjadi potret buram dalam dunia pendidikan Indonesia. Pada tahun 2010, setidaknya terjadi 128 kasus tawuran antarpelajar. Angka itu melonjak tajam lebih dari $100 \%$ pada 2011 , yakni 330 kasus tawuran yang menewaskan 82 pelajar. Pada Januari-Juni 2012, telah terjadi 139 tawuran yang menewaskan 12 pelajar (tvonenews.tv, 2012).

Seharusnya hal ini tidak terjadi jika siswa sadar akan tugasnya, tugas seorang siswa adalah belajar. Keberhasilan dari pembelajaran dipengaruhi oleh proses yang ada di dalam pembelajaran, apabila prosesnya baik maka hasilnya juga baik namun apabila prosesnya tidak baik maka bisa dikatakan hasil akhir yang akan didapat juga tidak baik.

Hal ini kurang disadari oleh guru dan orang tua bahwa proses pembelajaran merupakan faktor penting yang akan menunjang ke- berhasilan pembelajaran pada keseluruhan. $\mathrm{Gu}$ ru dan orang tua lebih senang jika nilai rapotnya baik, padahal belum tentu nilai akhir adalah hal yang paling baik atau paling bagus.

Menurut definisi Kimble (Hergenhahn dan Olson, 2009, p.8) belajar berasal dari praktek yang diperkuat, dengan kata lain, praktek atau proses sangat berpengaruh pada keberhasilan sebuah proses belajar. Keberhasilan sebuah proses pembelajaran juga dipengaruhi oleh faktor lain yaitu kualitas dari pembelajaran itu sendiri.

Kondisi kualitas pembelajaran saat ini sangat memperihatinkan, mulai dari sekolah dasar, sekolah menengah bahkan hingga tingkat atas. Sampai saat ini $88,8 \%$ sekolah di Indonesia mulai SD hingga SMA/SMK, belum melewati mutu standar pelayanan minimal. Pada pendidikan dasar hingga kini layanan pendidikan mulai dari guru, bangunan sekolah, fasilitas perpustakaan dan laboratorium, buku-buku pelajaran dan pengayaan, serta buku referensi masih minim. Pada jenjang Sekolah Dasar (SD) baru 3,29\% dari 146.904 yang masuk kategori sekolah standar nasional, 51,71\% kategori standar minimal dan 44,84\% di bawah standar pendidikan minimal. pada jenjang SMP $28,41 \%$ dari 34.185, 44,45\% berstandar minimal dan $26 \%$ tidak memenuhi standar pelayanan minimal. Hal tersebut membuktikan bahwa pendidikan di Indonesia tidak terpenuhi sarana prasarananya (Kompas: 2010). Ada beberapa faktor yang menunjang keberhasilan sebuah proses pendidikan yaitu faktor siswa, fasilitas pembelajaran dan guru. Menurut Undang-undang Guru dan Dosen $(2009$, p.61) guru adalah pendidik profesional dengan tugas utama mendidik, mengajar, membimbing, mengarahkan, melatih, menilai dan mengevaluasi peserta didik pada pendidikan anak usia dini lalu pendidikan formal, pendidikan dasar dan pendidikan menengah. Oleh karena itu, fungsi guru adalah sebagai pendidik, pengajar, pembimbing, pelatih, pengembang program, pengelola program dan tenaga profesional yang memiliki tugas dan fungsi untuk menggambarkan kompetensi yang harus dimiliki oleh guru profesional. Dalam Undang-undang Guru dan Dosen (2009, p.5) guru mempunyai kedudukan sebagai tenaga profesional pada jenjang pendidikan dasar, pendidikan menengah dan pendidikan anak usia dini pada jalur formal yang diangkat sesuai dengan peraturan perundang-undangan. Selain itu kedudukan guru sebagai tenaga profesional berfungsi untuk meningkatkan martabat dan peran 
guru sebagai agen pembelajaran berfungsi untuk meningkatkan mutu pendidikan nasional (Undang-undang Guru dan Dosen, 2009, p.5).

Dalam standar kompetensi guru disebutkan bahwa kompetensi inti guru meliputi penyelenggaraan pembelajaran yang mendidik dan pemanfaatan teknologi informasi dan komunikasi untuk kepentingan pembelajaran (Undang-undang Guru dan Dosen, 2009, pp.163164). Dalam kompetensi inti guru memiliki bagian kecil yakni guru harus mampu menggunakan media pembelajaran dan sumber belajar yang relevan dengan karakteristik peserta didik dan mata pelajaran yang diampu untuk mencapai tujuan pembelajaran secara utuh.

Selain itu, dalam kompetensi inti guru disebutkan bahwa guru harus mampu memanfaatkan teknologi informasi dan komunikasi untuk kepentingan pembelajaran. Sedangkan untuk kompetendi guru mata pelajaran disebutkan bahwa guru harus mampu memanfaatkan teknologi informasi dan komunikasi dalam pembelajaran yang diampu. Kemajuan teknologi membuat manusia secara sengaja atau tidak sengaja telah berinteraksi terhadap teknologi. Saat ini perkembangan teknologi semakin membantu manusia untuk mencapai hasil maksimal dalam segala bidang.

Salah satunya adalah peranan media komputer dengan berbagai softwere aplikasi untuk meningkatkan penyampaian suatu informasi. Informasi adalah suatu sumber daya yang dibutuhkan dalam mengelola bisnis. Hampir semua pekerjaan dapat dibantu dengan teknologi yang diciptakan oleh manusia, sehingga manusia dapat mempunyai daya guna dan tepat guna yang mampu mendorong kemajuan suatu bidang atau usaha.

Mulimedia merupakan salah satu bentuk aplikasi komputer yang dapat menyajikan suara, gambar dan animasi menjadi bentuk karya yang tidak hanya memberikan informasi yang dibutuhkan tetapi juga menarik dan dapat dinikmati oleh penggunanya. Pemanfaatan jelas tidak hanya untuk bidang periklanan bidang pariwisata, bidang pertelevisian dan broadcasting di mana multimedia dalam bidang tersebut mempunyai andil yang sangat besar bahkan sekarang pemanfaatannya untuk berbagai bidang.

Salah satu bidang yang mendapatkan dampak cukup berarti dengan perkembangan teknologi ini adalah bidang pendidikan. Pada dasarnya pendidikan merupakan suatu proses komunikasi dan informasi dari pendidik kepada peserta didik yang berisi informasi-informasi pendidikan, yang memiliki unsur-unsur pendidik sebagai sumber informasi.

Dampak perkembangan iptek terhadap proses pembelajaran adalah diperkayanya sumber dan media pembelajaran, seperti buku teks, modul, overhead transparansi, film, video, televisi, slide hypertext, web, dan sebagainya. Guru profesional dituntut mampu memilih dan menggunakan berbagai jenis media pembelajaran yang ada di sekitarnya.

Demikian juga dalam pembelajaran Penjas, guru Penjas harus mampu menggunakan media pembelajaran dalam proses pembelajaran. Walaupun pembelajaran pendidikan jasmani adalah pembelajaran yang dilakukan di luar ruangan namun tidak menutup kemungkinan bahwa pembelajaran mengenai materi teori juga membutuhkan peran multimedia. Dalam peranannya memberikan dorongan, kesadaran dan pengarahan kepada siswa harus menggunakan cara atau metode pengajaran yang dapat dengan mudah dipahami oleh siswa sehingga mampu didengarkan, dipahami, diresapi dan dilaksanakan sebagai dampak (feed back) dari hasil pembelajaran.

Pendidikan jasmani sangat berperan penting dalam mengurangi kenakalan remaja, selain pada saat pembelajaran lebih bersifar informal atau lebih santai dalam pendidikan jasmani juga memiliki tujuan yang diungkapkan oleh Depdiknas. Tujuan pendidikan jasmani yaitu meletakan landasan karakter moral yang kuat melalui internalisasi nilai dalam kehidupan, membangun landasan kepribadian yang kuat, sikap cinta damai, sikap sosial dan toleransi dalam konteks kemajukan budaya, etnis dan agama (Depdiknas, 2003, p.6).

Selain itu menumbuhkan kemampuan berfikir kritis melalui pelaksanaan tugas-tugas ajar pendidikan jasmani, mengembangkan sikap sportif, jujur, disiplin, bertanggung jawab, kerja sama, percaya diri, demokratis, kemampuan gerak, keterampilan pengelolaan diri, keterampilan menjaga keselamatan diri sendiri dan orang lain. Untuk mengetahui konsep aktifitas jasmani sebagai informasi untuk mencapai kesehatan, kebugaran, dan pola hidup sehat dan mampu memanfaatkan waktu luang untuk kesehatan dengan aktifitas jasmani yang bersifat rekreatif.

Pada kenyataannya tujuan dari pendidikan jasmani belum sepenuhnya bisa diterapkan. Masih banyak siswa kurang mengetahui makna dan tujuan pendidikan jasmani. Hal ini dikarenakan pembelajaran pendidikan jasmani 
saat ini masih monoton dan kurang menarik. Oleh karena itu pembelajaran pendidikan jasmani saat ini harus menggunakan bantuan media pembelajaran interaktif terutama untuk pembelajaran teori.

Salah satu kendala kurang lancarnya pembelajaran pendidikan jasmani di sekolah adalah kurang memadainya sarana yang dimiliki oleh sekolah tersebut. Di samping itu masih kuatnya ketergantungan para guru pendidikan jasmani pada sarana yang standar sesuai dengan kurikulum yang ditetapkan. Kedua hal tersebut menyebabkan pola pembelajaran yang kurang variatif dan cenderung membosankan bagi siswa.

Saat ini sarana dan prasarana untuk kegiatan pembelajaran pendidikan jasmani di sekolah-sekolah dasar masih memprihatinkan. Jangankan kuantitasnya, kualitas kelayakan untuk terselenggaranya kegiatan pendidikan jasmani yang nyaman masih jauh dari harapan. Hal ini sulit untuk dihindari, karena keberadaan sekolah yang semakin terasa sempit, apabila kebijakan pemerintah atau sekolah kurang berpihak pada kegiatan pendidikan jasmani. Tidak dapat dipungkiri bahwa di beberapa sekolah dasar hanya mempunyai lahan untuk kegiatan penjas berupa halaman untuk upacara bendera dan itupun sudah bisa dikatakan ada dan memadai karena di tempat itulah para siswa melakukan kegiatan jasmani.

Berdasarkan latar belakang di atas dapat diketahui masalah yang teridentifikasi adalah pembelajaran pendidikan jasmani saat ini masih monoton dan kurang menarik dan harus menggunakan bantuan media pembelajaran interaktif. Kedua, masih kuatnya ketergantungan para guru pendidikan jasmani pada sarana dan prasarana yang standar serta pendekatan pembelajaran pada penyajian teknik-teknik dasar sesuai dengan kurikulum yang ditentukan. Ketiga, saat ini sarana dan prasarana untuk kegiatan pembelajaran pendidikan jasmani di sekolah-sekolah dasar memperihatinkan. Keempat, kurangnya media pembelajaran pendidikan jasmani khususnya untuk pembelajaran teori.

Penelitian dan pengembangan memiliki tujuan untuk menghasilkan sebuah produk berupa $\mathrm{CD}$ dan buku petunjuk pembelajaran pendidikan jasmani materi budaya hidup sehat. Multimedia ini dapat dioperasikan menggunakan bantuan komputer dan diharapkan dengan adanya $C D$ pembelajaran ini dapat mengatasi keterbatasan media pembelajaran khususnya mata pelajaran teori. Diharapkan dengan adanya multimedia dan buku petunjuk tersebut membantu meningkatkan kualitas pembelajaran teori pada saat melaksanakan pembelajaran pendidikan jasmani materi budaya hidup sehat.

Hasil peneitian ini diharapkan menghasilkan sebuah produk yang bermanfaat bagi siswa, bahwa produk ini bisa digunakan sebagai media pembelajaran yang efektif dan mempermudah pemahaman siswa mengenai mata pelajaran budaya hidup sehat serta produk ini juga akan membiasakan siswa dengan pembelajaran yang berbasis komputer. Bagi guru, untuk meningkatkan kualitas pembelajaran yang disampaikannya sehingga siswa akan lebih mudah menyerap materi yang akan disampaikan.

Bagi peneliti, hasil penelitian ini bisa memberikan manfaat bagi peneliti mengenai media yang efektif dan mampu mengikuti perkembangan teknologi di dunia pendidikan serta diharapkan banyak muncul media-media pembelajaran yang lainnya. Bagi lembaga pendidikan, penelitian ini sangat bermanfaat bagi lembaga pendidikan dalam penggunaan metode pembelajan berbasis komputer dan sebagai pelengkap media pembelajaran yang sudah ada.

\section{Metode}

\section{Jenis Penelitian}

Penelitian ini adalah penelitian dan pengembangan (research and development) melalui uji coba produk di lapangan. Penelitian ini merupakan model penelitian yang bertujuan membuat dan mengembangkan multimedia pembelajaran untuk membantu guru mata pelajaran pendidikan jasmani dalam hal materi budaya hidup sehat.

\section{Waktu dan Tempat Penelitian}

Penenlitian ini dilakukan selama 3 bulan yakni bulan Maret 2013 sampai dengan bulan Mei 2013 dengan rincian sebagai berikut, Uji satu lawan satu pada bulan Maret di SMAN 1 Yogyakarta, SMAN 2 Yogyakarta, dan SMA N 7 Yogyakarta. Untuk uji lapangan awal pada bulan April di SMAN 1 Yogyakarta, SMAN 2 Yogyakarta, SMAN 3 Yogyakarta, SMAN 7 Yogyakarta, dan SMAN 8 Yogyakarta. Untuk uji lapangan operasional dilaksanakan pada bulan Mei di 11 SMA Negeri se-Kota Yogyakarta.

\section{Target/Subjek Penelitian}

Target penelitian ini adalah siswa siswa kelas X (sepuluh) XI (sebelas) dan XII (dua belas) SMA se-Kota Yogyakarta. Teknik me- 
meroleh subjek adalah dengan meminta bantuan gutu mata pelajaran untuk memilih siswa dengan kemampuan rendah, kemampuan sedang dan kemampuan tinggi untuk membandingkan kecepatan penerimaan materi yang diberikan dalam CD pembelajaran dan buku petunjuk $C D$ pembelajaran.
Prosedur

Berdasarkan penjelasan di atas, prosedur penelitian dan pengembangan yang dilakukan dalam penelitian ini dikelompokkan menjadi empat langkah yang tersaji sebagai berikut.

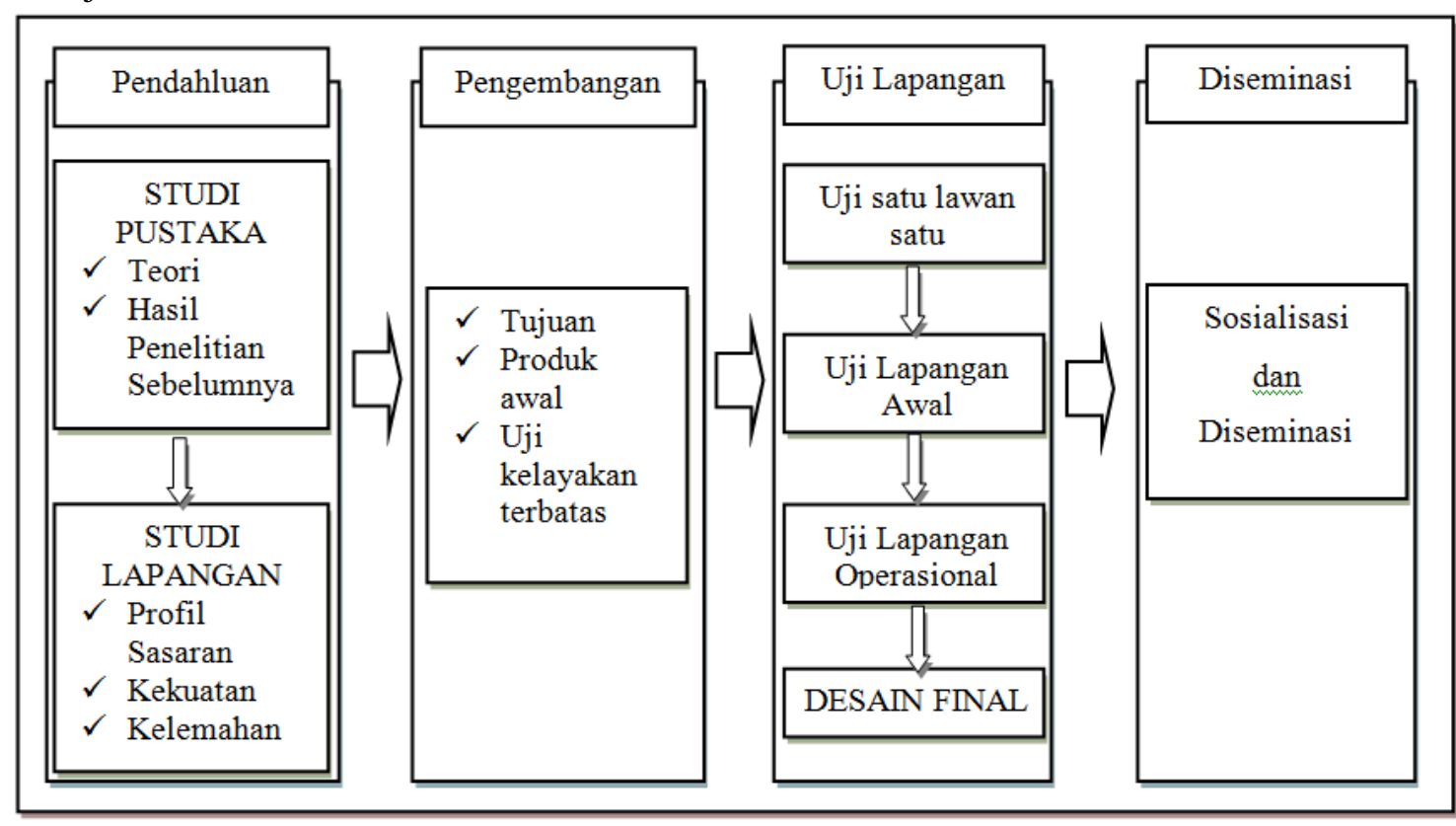

Gambar 1. Prosedur Penelitian dan Pengembangan

\section{Studi Pendahuluan}

Studi pendahuluan dilakukan dalam dua bentuk, yaitu studi pustaka dan survei terhadap kondisi empirik penelitian. Setelah melakukan kajian teori kemudian melakukan survei lapangan untuk mengetahui kondisi nyata di lapangan sebagai tempat berlangsungnya aktifitas yang menjadi sasaran penelitian.

\section{a. Studi Pustaka}

Setelah fokus masalah diketahuai, selanjutnya adalah mencari teori-teori yang berkaitan dengan fokus penelitian. Dalam hal ini teori yang dicari mengenai budaya hidup sehat baik mengenai permasalahan narkoba, seks bebas, HIV/AIDS, pemanfaatan waktu luang hingga pola hidup sehat itu sendiri.

Mata pelajaran yang akan diproduksi dalam CD pembelajaran adalah mata pelajaran pendidikan jasmani, karena sesuai dengan kompetensi peneliti yang mengambil kuliah Jurusan Pendidikan Olahraga Rekreasi (POR) Program Studi Pendidikan Jasmani Kesehatan dan Rekreasi (PJKR). Materi yang akan dibentuk menjadi CD pembelajaran mengaju pada kurikulum
2006 atau Kurikulum Tingkat Satuan Pendidikan (KTSP).

b. Studi Lapangan

Studi lapangan dilakukan pada bulan November 2012 di 4 SMA Negeri di Kota Yogyakarta yakni, SMAN 2, SMAN 3, dan SMAN 8 Yogyakarta dan hasilnya adalah materi yang digunakan oleh sekolah tersebut sesuai dengan standar isi yang peneliti dapat dari dinas pendidikan Kota Yogyakarta.

Mengacu pada kenyataan di lapangan maka produk ini akan dirancang dan disertai tambahan-tambahan aplikasi lain untuk menarik perhatian siswa. Produk ini disertai dengan teks dan gambar yang berkaitan dengan budaya hidup sehat.

\section{Pengembangan}

a. Tujuan

Penelitian dan pengembangan memiliki tujuan untuk menghasilkan sebuah produk berupa $\mathrm{CD}$ dan buku petunjuk pembelajaran pendidikan jasmani materi budaya hidup sehat. Multimedia ini dapat dioperasikan menggunakan bantuan komputer dan diharapkan dengan adanya $\mathrm{CD}$ pembelajaran ini dapat mengatasi 
keterbatasan media pembelajaran khususnya mata pelajaran teori. Diharapkan dengan adanya multimedia dan buku petunjuk tersebut membantu meningkatkan kualitas pembelajaran teori pada saat melaksanakan pembelajaran pendidikan jasmani materi budaya hidup sehat.

b. Produk Awal

\section{Penyusunan Flowcard}

Flowchart merupakan gambar atau bagan yang memperlihatkan urutan dan hubungan antarproses beserta instruksinya. Gambaran ini dinyatakan dengan simbol. Dengan demikian setiap simbol menggambarkan proses tertentu. Sedangkan hubungan antarproses digambarkan dengan garis penghubung.

Flowchart ini merupakan langkah awal pembuatan program. Dengan adanya flowchart urutan poses kegiatan menjadi lebih jelas. Jika ada penambahan proses maka dapat dilakukan lebih mudah. Setelah flowchart selesai disusun, selanjutnya pemrogram (programmer) menerjemahkannya ke bentuk program dengan bahasa pemrograman.

Dalam tahap ini peneliti menyusun flowchart untuk memudahkan penyusunan pada program Adobe Flash CS3. Peneliti menyusun 3 flowchart karena produk yang akan dikembangkan sebanyak tiga buah yakni kelas X, kelas XI dan kelas XII.

\section{Penyusunan Story Board}

Storyboard adalah sketsa gambar yang disusun berurutan sesuai dengan naskah, dengan storyboard kita dapat menyampaikan ide cerita kita kepada orang lain dengan lebih mudah, karena kita dapat menggiring khayalan seseorang mengikuti gambar-gambar yang tersaji, sehingga menghasilkan persepsi yang sama pada ide cerita.

Hal ini juga dilakukan pada saat penyusunan multimedia pendidikan khususnya dalam CD pembelajaran agar cerita yang akan disampaikan tidak melenceng terlalu jauh. Penyusunan ini juga dilakukan tiga kali karena produk yang akan dibuat sebanyak tiga buah yakni kelas X, kelas XI dan kelas XII.

\section{Penyusunan Prototype}

Setelah model pengembangan berdasarkan studi pustaka dan studi lapangan, tahap selanjutnya adalah menganalisis kisi-kisi produk yang dibuat apakah sesuai dengan teori dan keadaan di lapangan atau tidak. Gambaran se- cara umum, proses penilaian produk ini adalah mengenai tampilan produk, kesesuaian materi dan animasi.

Selanjutnya adalah penyusunan butirbutir penilaian berdasarkan indikator yang telah ditentukan. Penyusunan butir disertai dengan penyusunan pelaksanaan dan prosedur pelaksanaan beserta skor. Setelah penyusunan butirbutir evaluasi selesai dilanjutkan dengan penilaian expert judgment terhadap butir tersebut.

Penilaian dan validasi expert judgment adalah untuk memeriksa tampilan, isi dan bentuk prodik yang akan dibuat. Hal ini dilakukan untuk memvalidasi butir penilaian berkaitan dengan produk yang dibuat. Dalam hal ini judgment terdiri dari ahli materi, ahli media dan ahli evaluasi.

\section{Uji Kelayakan Terbatas}

a) Uji Ahli Materi

Uji kelayakan terbatas yang pertama adalah dari ahli materi, dalam tahap ini judgment yang ditunjuk berasal dari dosen Ilmu Keolahragaan sesuai dengan materi yang akan dikembangakan dalam multimedia. Dalam tahap ini dilakukan dua kali revisi mengenai CD pembelajaran dan buku petunjuk penggunaan CD pembelajaran.

\section{b) Uji Ahli Media}

Uji kelayakan terbatas yang kedua adalah dari ahli media. dalam tahap ini judgment yang ditunjuk berasal dari dosen Teknologi Pembelajaran Program Pascasarjana Universitas Negeri Yogyakarta sesuai dengan materi yang akan dikembangakan dalam multimedia. Dalam tahap ini dilakukan dua kali revisi mengenai $\mathrm{CD}$ pembelajaran dan buku petunjuk penggunaan CD pembelajaran.

\section{c) Uji Ahli Tes dan Evaluasi}

Uji kelayakan terbatas yang ketiga adalah dari ahlites dan evaluasi, dalam tahap ini judgment yang ditunjuk berasar dari dosen Ilmu Keolahragaan Program Pascasarjana Universitas Negeri Yogyakarta sesuai dengan materi yang akan dikembangakan dalam multimedia. Dalam tahap ini dilakukan dua kali revisi mengenai $\mathrm{CD}$ pembelajaran dan buku petunjuk penggunaan $\mathrm{CD}$ pembelajaran. 


\section{Uji Lapangan}

\section{a. Uji Satu Lawan Satu}

Setelah Proses pengembangan dan proses validasi selesai tahap selanjutnya adalah penelitian dilapangan. Pada tahap ini dilaksanakan uji satu-satu dengan menggunakan tiga sekolah di kota Yogyakarta. SMA tersebut adalah SMAN 1 Yogyakarta, SMAN 2 Yogyakarta dan SMAN 7 Yogyakarta. Penelitian di SMAN 1 Yogyakarta dilaksanakan pada tanggal 7 dan 8 Maret 2013 dengan menggunakan 1 siswa kelas $X$ dan 1 siswa kelas XI. Di SMAN 2 Yogyakarta dilaksanakan pada tanggal 11 dan 12 Maret 2013, dan SMAN 7 Yogyakarta pada tanggal 15 Maret 2013.

\section{b. Uji Lapangan Awal}

Setelah uji satu-satu selesai dilaksanakan dan dilakukan analisis data serta dilaksanakan revisi mengenai produk yang dikembangkan maka tahap selanjutnya adalah uji lapangan awal atau uji kelas kecil dengan menggunakan 5 SMA dengan jumlah responden 30 siswa. Pada tahap ini sekolah yang digunakan adalah SMAN 1 Yogyakarta SMAN 2 Yogyakarta, SMAN 3 Yogyakarta, SMAN 7 Yogyakarta dan SMAN 8 Yogyakarta.

SMAN 1 Yogyakarta pada tanggal 3 dan 4 April 2013, SMAN 2 Yogyakarta pada tanggal 5 April 2013, SMAN 3 pada tanggal 8 dan 9 April 2013, SMAN 7 Pada 11 April dan SMAN 8 pada 12 dan 13 April 2013.

\section{c. Uji Lapangan Operasional}

Setelah uji coba lapangan awal atau uji kelas kecil selesai dilaksanakan dan dilakukan analisis data serta dilaksanakan revisi mengenai produk yang dikembangkan maka tahap selanjutnya adalah uji lapangan operasional atau uji kelas besar dengan menggunakan 11 SMA dengan jumlah responden 44 siswa. Pada tahap ini sekolah yang digunakan adalah SMAN se-Kota Yogyakarta

Penelitian di SMAN 1 Yogyakarta dilaksanakan pada tanggal 7 dan 8 Mei 2013, SMAN 2 Yogyakarta pada 3 Mei 2013, SMAN 3 Yogyakarta pada 21 Mei 2013, SMAN 4 Yogyakarta pada 17 Mei 2013, SMAN 5 Yogyakarta pada 28 Mei 2013, SMAN 6 Yogyakarta pada 23 dan 24 Mei 2013, SMAN 7 Yogyakarta pada 14 Mei 2013, SMAN 8 Yogyakarta pada 15 Mei 2013, SMAN 9 Yogyakarta pada 23 Mei 2013, SMAN 10 Yogyakarta pada
25 dan 26 Mei 2013, SMAN 11 Yogyakarta pada 22 Mei 2013

d. Desain Final

Setelah tahap pengembangan dan tahap uji coba produk selesai dilaksanakan serta menganalisis data dan revisi produk selesai dilaksanakan maka tahap selanjutnya adalah penyusunan desain final. Pada tahap ini adalah penyempurnaan produk berupa $\mathrm{CD}$ pembelajaran dan buku petunjuk.

\section{Sosialisasi dan Desiminasi}

Setelah semua tahap dilakukan dan tidak ada revisi maka tahap selanjutnya adalah sosialisai dan desiminasi kepada guru dan siswa di SMAN se-Kota Yogyakarta. Tahap ini dilakukan dengan tujuan untuk memerkenalkan multimedia yang telah disusun kepada guru dan siswa sehingga pembelajaran pendidikan jasmani khususnya pembelajaran teori bisa lebih menarik perhatian siswa.

\section{Teknik Analisis Data}

Data yang sudah dihimpun dari angket kemudian dianalisis dengan menggunakan teknik deskriptis. Bentuk data kualitatif berupa pernyataan dapat dilihat pada Tabel 1 .

Tabel 1. Skor dan Kriteria Penilaian

\begin{tabular}{cc}
\hline Skor & Kriteria \\
\hline 5 & Sangat Baik \\
4 & Baik \\
3 & Cukup Baik \\
2 & Kurang baik \\
1 & Sangat kurang baik \\
\hline
\end{tabular}

Untuk skor yang diperoleh, dikonversikan menjadi nilai pada skala 5 (Sukardjanto, 2005, p.55) yang diperhatikan seperti tabel 2 Berikut ini.

Tabel 2. Konversi Skor ke Nilai pada Skala 5

\begin{tabular}{ccc}
\hline Interval Skor & Nilai & Kategori \\
\hline $\mathrm{X}>X i+1,80 \mathrm{SBi}$ & $\mathrm{A}$ & $\begin{array}{c}\text { Sangat } \\
\text { Baik }\end{array}$ \\
$X i+0,60 \mathrm{SBi}<\mathrm{X} \leq X i+1,80 \mathrm{SBi}$ & $\mathrm{B}$ & $\begin{array}{c}\text { Baik } \\
\text { Cukup } \\
\text { Baik }\end{array}$ \\
$X i-0,60 \mathrm{SBi}<\mathrm{X} \leq X i+0,60 \mathrm{SBi}$ & $\mathrm{C}$ & $\begin{array}{c}\text { Kurang } \\
\text { Baik }\end{array}$ \\
$X i-1,80 \mathrm{SBi}<\mathrm{X} \leq X i-0,60 \mathrm{SBi}$ & $\mathrm{D}$ & $\begin{array}{c}\text { Sangat } \\
\text { Kurang } \\
\text { Baik }\end{array}$ \\
$\mathrm{X}<X i-1,80 \mathrm{SBi}$ & $\mathrm{E}$ &
\end{tabular}

Keterangan:

$X i \quad=$ Rerata ideal 


$$
\begin{array}{ll} 
& =1 / 2(\text { skor maksimal ideal }+ \text { skor } \\
& \text { minimal ideal) } \\
\text { SBi } & \text { Simpangan Baku ideal = } 1 / 6 \text { (skor } \\
& \text { maksimal ideal-skor minimal ideal) } \\
\mathrm{X} & =\text { Skor siswa hasil uji coba }
\end{array}
$$

\section{Hasil Penelitian dan Pengembangan}

Hasil pengembangan dalam penelitian pengembangan ini adalah berupa multimedia pembelajaran pendidikan jasmani materi budaya hidup sehat yang ditujukan untuk siswa kelas X, kelas XI dan kelas XII. Multimedia ini berupa $\mathrm{CD}$ pembelajaran dan buku petunjuk $\mathrm{CD}$. Materi yang ada dalam CD pembelajaran dan buku petunjuk adalah bahaya penggunaan narkoba, bahaya seks bebas untuk kelas $\mathrm{X}$, bahaya HIV/AIDS dan pemanfaatan waktu luang untuk kelas XI dan pola hidup sehat untuk kelas XII.

\begin{tabular}{|c|c|c|c|}
\hline No & Butir Pertanyaan & $\begin{array}{r}\text { Kategori } \\
(\text { Kelas X) } \\
\end{array}$ & $\begin{array}{c}\text { Kategori } \\
\text { (Kelas XI) } \\
\end{array}$ \\
\hline 1 & $\begin{array}{l}\text { Kejelasan } \\
\text { petunjuk } \\
\text { penggunaan } \\
\text { produk }\end{array}$ & $\begin{array}{l}\text { Sangat } \\
\text { Mudah }\end{array}$ & $\begin{array}{l}\text { Sangat } \\
\text { Mudah }\end{array}$ \\
\hline 2 & $\begin{array}{l}\text { Kemudahan } \\
\text { memulai program }\end{array}$ & $\begin{array}{l}\text { Sangat } \\
\text { Mudah }\end{array}$ & $\begin{array}{l}\text { Sangat } \\
\text { Mudah }\end{array}$ \\
\hline 3 & $\begin{array}{l}\text { Kemudahan } \\
\text { mengakhiri } \\
\text { program }\end{array}$ & $\begin{array}{l}\text { Sangat } \\
\text { Mudah }\end{array}$ & $\begin{array}{l}\text { Sangat } \\
\text { Mudah }\end{array}$ \\
\hline 4 & $\begin{array}{l}\text { Kemudahan } \\
\text { memilih menu } \\
\text { materi }\end{array}$ & $\begin{array}{l}\text { Sangat } \\
\text { Mudah }\end{array}$ & $\begin{array}{l}\text { Sangat } \\
\text { Mudah }\end{array}$ \\
\hline 5 & $\begin{array}{l}\text { Kemudahan } \\
\text { menggunakan } \\
\text { tombol }\end{array}$ & $\begin{array}{l}\text { Sangat } \\
\text { Mudah }\end{array}$ & Mudah \\
\hline 6 & $\begin{array}{l}\text { Konsistensi tata } \\
\text { letak tombol } \\
\text { Tingkat }\end{array}$ & Mudah & Mudah \\
\hline 7 & $\begin{array}{l}\text { kemudahan } \\
\text { menggunakan } \\
\text { aplikasi }\end{array}$ & $\begin{array}{l}\text { Sangat } \\
\text { Mudah }\end{array}$ & Mudah \\
\hline 8 & $\begin{array}{l}\text { Kejelasan } \\
\text { petunjuk } \\
\text { mengerjakan soal }\end{array}$ & Mudah & $\begin{array}{l}\text { Sangat } \\
\text { Mudah }\end{array}$ \\
\hline 9 & $\begin{array}{l}\text { Kebebasan } \\
\text { memilih menu } \\
\text { materi }\end{array}$ & Mudah & $\begin{array}{l}\text { Sangat } \\
\text { Mudah }\end{array}$ \\
\hline 10 & $\begin{array}{l}\text { Mudah } \\
\text { menggunakan } \\
\text { navigasi (link) }\end{array}$ & Mudah & $\begin{array}{l}\text { Sangat } \\
\text { Mudah }\end{array}$ \\
\hline
\end{tabular}

Tabel 3. Data Tanggapan Siswa Kelas X Aspek Kemudahan CD untuk Dioperasika dalam Uji

Coba Lapangan Multimedia Pembelajaran Budaya Hidup Sehat untuk SMA
Tabel 4. Data Tanggapan Siswa Kelas X Aspek Kemudahan CD Pembelajaran untuk Dipelajari dalam Uji Coba LapanganMultimedia Pembelajaran Budaya Hidup Sehat untuk SMA

\begin{tabular}{clcc}
\hline No & \multicolumn{1}{c}{ Butir Pertanyaan } & Kelas X & Kelas XI \\
\hline 1 & $\begin{array}{l}\text { Kejelasan rumusan } \\
\text { SK/KD CD } \\
\text { Pembelajaran }\end{array}$ & Mudah & Mudah \\
2 & $\begin{array}{l}\text { Kejelasan urutan materi } \\
\text { antara CD pembelajaran } \\
\text { untuk dipelajari }\end{array}$ & $\begin{array}{l}\text { Sangat } \\
\text { Mudah }\end{array}$ & Mudah \\
& $\begin{array}{l}\text { Ketepatan urutan } \\
\text { penyampaian materi } \\
\text { antara CD pembeajaran }\end{array}$ & Mudah & Mudah \\
4 & $\begin{array}{l}\text { Penyampaian materi } \\
\text { menarik }\end{array}$ & Mudah & Mudah \\
& $\begin{array}{l}\text { Penggunaan teks dan } \\
\text { gaya bahasa dalam CD }\end{array}$ & Mudah & Mudah \\
Pembelajaran & $\begin{array}{l}\text { Keterbacaan teks dalam } \\
\text { CD Pembelajaran }\end{array}$ & Mudah & Mudah \\
7 & $\begin{array}{l}\text { Kejelasan butir soal tes } \\
\text { untuk dikerjakan } \\
\text { Penggunaan } \\
\text { gambar/foto/animasi } \\
\text { antara CD Pembelajaran } \\
\text { mendukung } \\
\text { pembelajaran }\end{array}$ & Mudah & Mudah \\
\hline
\end{tabular}

\begin{tabular}{|c|c|c|c|}
\hline No & Butir Pertanyaan & Kelas X & Kelas XI \\
\hline 1 & $\begin{array}{l}\text { Kejelasan rumusan } \\
\text { SK/KD dalam buku } \\
\text { petunjuk }\end{array}$ & Mudah & Mudah \\
\hline 2 & $\begin{array}{l}\text { Kejelasan urutan } \\
\text { materi dalam buku } \\
\text { petunjuk untuk } \\
\text { dipelajari }\end{array}$ & Mudah & Mudah \\
\hline 3 & $\begin{array}{l}\text { Ketepatan urutan } \\
\text { penyampaian materi } \\
\text { buku petunjuk }\end{array}$ & Mudah & Mudah \\
\hline 4 & $\begin{array}{l}\text { Penggunaan teks dan } \\
\text { gaya bahasa dalam } \\
\text { buku petunjuk } \\
\text { menarik }\end{array}$ & Mudah & Mudah \\
\hline 5 & $\begin{array}{l}\text { Keterbacaan teks } \\
\text { dalam buku petunjuk }\end{array}$ & Mudah & Mudah \\
\hline 6 & $\begin{array}{l}\text { Kejelasan butir soal } \\
\text { tes untuk dikerjakan }\end{array}$ & $\begin{array}{l}\text { Sangat } \\
\text { Mudah }\end{array}$ & Mudah \\
\hline 7 & $\begin{array}{l}\text { Penggunaan gambar } \\
\text { atau foto atau animasi } \\
\text { dalam buku } \\
\text { mendukung } \\
\text { pembelajaran }\end{array}$ & Mudah & $\begin{array}{l}\text { Cukup } \\
\text { Mudah }\end{array}$ \\
\hline
\end{tabular}

Tabel 5. Data Tanggapan Siswa Kelas X Aspek

Kemudahan Buku Petunjuk untuk Dipelajari dalam Uji Coba Lapangan Multimedia

Pembelajaran Budaya Hidup Sehat untuk SMA 
Tabel 6. Data Tanggapan Siswa Kelas X Aspek Kemenarikan CD Pembelajaran dan Buku Petunjuk dalam Uji Coba Lapangan Multimedia Pembelajaran Budaya Hidup Sehat untuk SMA

\begin{tabular}{|c|c|c|c|}
\hline No & Butir Pertanyaan & Kelas X & Kelas XI \\
\hline 1 & $\begin{array}{l}\text { Keserasian dan } \\
\text { keseimbangan layar } \\
\text { CD }\end{array}$ & Menarik & Menarik \\
\hline 2 & $\begin{array}{l}\text { Kemenarikan } \\
\text { warna CD dan buku }\end{array}$ & $\begin{array}{l}\text { Sangat } \\
\text { Menarik }\end{array}$ & $\begin{array}{l}\text { Cukup } \\
\text { Menarik }\end{array}$ \\
\hline 3 & $\begin{array}{l}\text { Kemenarikan } \\
\text { desain CD dan } \\
\text { buku }\end{array}$ & Menarik & Menarik \\
\hline 4 & $\begin{array}{l}\text { Keserasian dan } \\
\text { kemenarikan } \\
\text { tombol dalam CD }\end{array}$ & Menarik & Menarik \\
\hline 5 & $\begin{array}{l}\text { Ketepatan tata letak } \\
\text { teks dalam CD dan } \\
\text { buku }\end{array}$ & Menarik & Menarik \\
\hline 6 & $\begin{array}{l}\text { Keserasian } \\
\text { pemeilihan huruf, } \\
\text { ukuran huruf dan } \\
\text { spasi tulisan dalam } \\
\text { CD dan buku }\end{array}$ & Menarik & $\begin{array}{l}\text { Cukup } \\
\text { Menarik }\end{array}$ \\
\hline 7 & $\begin{array}{l}\text { Kesesuaian warna } \\
\text { latar CD dengan } \\
\text { warna huruf }\end{array}$ & Menarik & Menarik \\
\hline 8 & $\begin{array}{l}\text { Keserasian antara } \\
\text { teks, gambar di CD } \\
\text { dan buku }\end{array}$ & $\begin{array}{l}\text { Sangat } \\
\text { Menarik }\end{array}$ & Menarik \\
\hline
\end{tabular}

\section{Simpulan dan Saran}

Simpulan

Pengembangan multimedia pembelajaran dalam penelitian ini telah dilaksanakan dengan menggunakan model adaptasi pengembangan produk dari model Borg \& Gall (1983, p.775).

Berdasarkan hasil pengolahan data penelitian, simpulan dari penelitian ini adalah tanggapan dari ahli materi terhadap pengembangan multimedia pendidikan jasmani ini adalah baik. Rata-rata penilaian CD dan buku kelas $\mathrm{X}$ dari ahli materi adalah 4,73 yang berarti sangat baik. Untuk penilaian CD dan buku kelas XI dari ahli materi adalah 4,73 yang berarti sangat baik. Tanggapan ahli media terhadap multimedia pembelajaran pendidikan jasmani ini adalah baik. Rata-rata penilaian CD dan bu$\mathrm{ku}$ kelas $\mathrm{X}$ dari ahli media adalah 4,23 yang berarti sangat baik. Untuk penilaian $\mathrm{CD}$ dan buku kelas XI dari ahli media adalah 4,23 yang berarti sangat baik.

Tanggapan siswa dalam tahap preliminary field testing, rata-rata tanggapan siswa mengenai $\mathrm{CD}$ dan buku kelas $\mathrm{X}$ pada aspek pengoperasian $\mathrm{CD}$ sebesar 3,53 (baik), aspek pembelajaran $\mathrm{CD} 3,78$ (baik), pembelajaran buku 3,52 (baik) dan kemenarikan CD dan buku sebesar 3,75 (baik). Untuk kelas XI pada aspek pengoperasian CD sebesar 4,46 (sangat baik), aspek pembelajaran CD 3,84 (baik), pembelajaran buku 3,76 (baik) dan kemenarikan CD dan buku sebesar 3,71 (baik).

Dalam tahap main field testing skor rata-rata pretest kelas X adalah 48,67, sedangkan posttest adalah 79,00 . Selisih kenaikan adalah 30,33 sehingga persentase kenaikan antara pretest dan posttest adalah $62,32 \%$. Untuk kelas XI nilai rata-rata pretest adalah 54,67, sedangkan posttest adalah 79,33. Selisih kenaikan adalah 24,66 sehingga persentasi kenaikan antara pretest dan posttest adalah $45,11 \%$.

Dalam tahap operational field testing rata-rata tanggapan siswa mengenai $\mathrm{CD}$ dan buku kelas $\mathrm{X}$ pada aspek pengoperasian $\mathrm{CD}$ sebesar 4,60 (sangat baik), aspek pembelajaran CD 4,13 (baik), pembelajaran buku 4,14 (baik) dan kemenarikan CD dan buku sebesar 4,25 (sangat baik). Untuk kelas XI pada aspek pengoperasian CD sebesar 4,70 (sangat baik), aspek pembelajaran CD 3,86 (baik), pembelajaran buku 3,86 (baik) dan kemenarikan CD dan buku sebesar 3,75 (baik).

Saran

Penggunaan produk ini baik untuk siswa dan untuk guru pendidikan jasmani disarankan untuk memanfaatkan CD dan buku secara maksimal agar mendapatkan wawasan tentang pembelajaran pendidikan jasmani khususnya pembelajaran teori secara efektif. Harapan selanjutnya, pembelajaran pendidikan jasmani khususnya pembelajaran teori bisa lebih menarik perhatian siswa karna untuk materi kesehan juga sangat penting bagi siswa

\section{Daftar Pustaka}

Badan Narkotika Nasional. (2009). Undangundang RI nomor 35 tahun 2009, tentang narkotika.

Borg, W. R. \& Gall, M. D. (1983). Educational research: an introduction. Fourth edition. New York: Longman.

Hergenhahn, B. R. \& Olson, Matthew H. (2009). Theories of learning (teori belajar). Jakarta: Kencana. 
Data tawuran pelajar selama 2010-2012. (27 September 2012). Tvonenews.tv dari http://video.tvonenews.tv/arsip/view/62 132/2012/09/27/data_tawuran_pelajar _selama_20102012.tvOne.

Depdiknas. (2003). Kurikulum 2004; Standar kompetensi mata pelajaran pendidikan jasmani SD dan MI. Jakarta: Balitbang Depdiknas.

Dahar, R. W. (1989). Teori-teori belajar. Jakarta: Erlangga.
Munadi, Y. (2013). Media pembelajaran (sebuah pendekatan baru). Jakarta: REFERENSI (GP Press Group).

Sanjaya, W. (2009). Strategi pembelajaran beroruentasi standar proses pendidikan. Jakarta: Kencana Prenada Media Grup.

Winkel, W.S.. (1991). Psikologi pendidikan. Jakarta: Grasindo. 